B. Basok, Dr. Eng. Sc., Prof., ORCID 0000-0002-8935-4248

O. Nedbailo, Dr. Eng. Sc., SRF, ORCID 0000-0003-1416-9651

I. Bozhko, Cand. Sc. (Eng.), ORCID 0000-0001-7458-0835

M. Tkachenko, Cand. Sc. (Eng.), ORCID 0000-0001-8345-1613

Institute of Engineering Thermophysics of National Academy of Sciences of Ukraine

\title{
TECHNICAL FEATURES OF USING A COMPLEX WIND-SOLAR POWER SUPPLY SYSTEM OF AN ENERGY-EFFICIENT HOUSE
}

The wish to achieve energy savings of organic fuel while reducing the negative man-made impact on the environment, especially in the context of global warming, encourages for the search for new approaches in the construction of energy efficient houses and buildings. Analysis of the accumulated meteorological data on wind and solar potentials in Kyiv shows that in an urban city it is possible to create a fully autonomous house, which will be supplied with electricity using solar and wind energy. Year-round monitoring of atmospheric parameters such as current values of wind speed and direction, relative humidity and barometric air pressure was carried out using a portable meteorological station TFA Nexus using appropriate Primus software, which allowed to collect and analyze measurement data. Data on insolation for the location of the energy-efficient house were obtained experimentally in 2019 using measurements with a pyranometer SR-U1. The developed system consists of a wind generator, solar modules, charge controllers, inverters and batteries. The calculation of electricity production by the solar station was performed in the PVSyst program according to meteorological data Meteonorm. At the same time, it should be noted that the energy contribution from photomodules is crucial for the power supply of an energy-efficient house. The proposed instrumental methods for determining the parameters of insolation provide an opportunity to assess its technically available potential for a given area, as well as to use the obtained data for the design of complex power supply systems using energy of wind and solar. The research results prove that in the conditions of the city of Kyiv there are potential opportunities for the creation of residential buildings with zero energy balance, in which, for the purpose of power supply, wind generators and solar modules can be used quite successfully.

Keywords: wind-solar power supply system, electricity production, insolation.

\section{Introduction}

The wish to achieve energy savings of organic fuel while reducing the negative man-made impact on the environment, especially in the context of global warming, encourages for the search for new approaches in the construction of energy efficient houses and buildings. One of the approaches to solving the above problem is to create passive and "0-energy" houses $[1,2]$.

On the territory of the Institute of Engineering Thermophysics of the National Academy of Sciences of Ukraine in Kyiv, an energy-efficient house has been implemented as a scientific, technical and technological thermophysical laboratory. The experimental building investigates and optimizes air conditioning systems using renewable energy sources, advanced technologies for automation and informatization of heat transfer processes in energy supply systems. The successful implementation of this project clearly demonstrates the possibility of creating houses with zero energy balance in the climatic conditions of northern Ukraine, and its operation will provide a large amount of experimental scientific and practical information. At the same time, a consistent implementation of the technological chain is carried out: high energy efficiency house - passive house - intelligent house - Micro Smart-Grid-0-Energy system.

\section{Materials and methods of research}

The average annual amount of total solar radiation received per $1 \mathrm{~m} 2$ of surface in Ukraine is in the range from $1070 \mathrm{kWh} / \mathrm{m}^{2}$ in the northern part of Ukraine and up to $1400 \mathrm{kWh} / \mathrm{m}^{2}$ in the southern.

In the conditions of climate of Ukraine with the help of wind turbines it is possible to use $15 \div 19 \%$ of the volume of wind energy passing through the cross section of the windmill surface. The expected volumes of electricity production from $1 \mathrm{~m}^{2}$ of cross section of the wind wheel area in promising regions are more than $800 \div$ $1000 \mathrm{kWh} / \mathrm{m}^{2}$ per year.

Analysis of the accumulated meteorological data on wind and solar potentials in Kyiv shows that in an urban city it is possible to create a fully autonomous house, which will be supplied with electricity using solar and wind energy.

The developed system consists of a wind generator, solar modules, charge controllers, inverters and batteries (Fig. 1). To reserve and ensure uninterrupted operation, the system provides automatic input of reserve or the involvement of a diesel generator [3].

(C) Б.І. Басок, О.М. Недбайло, І.К. Божко, М.В. Ткаченко, 2021 


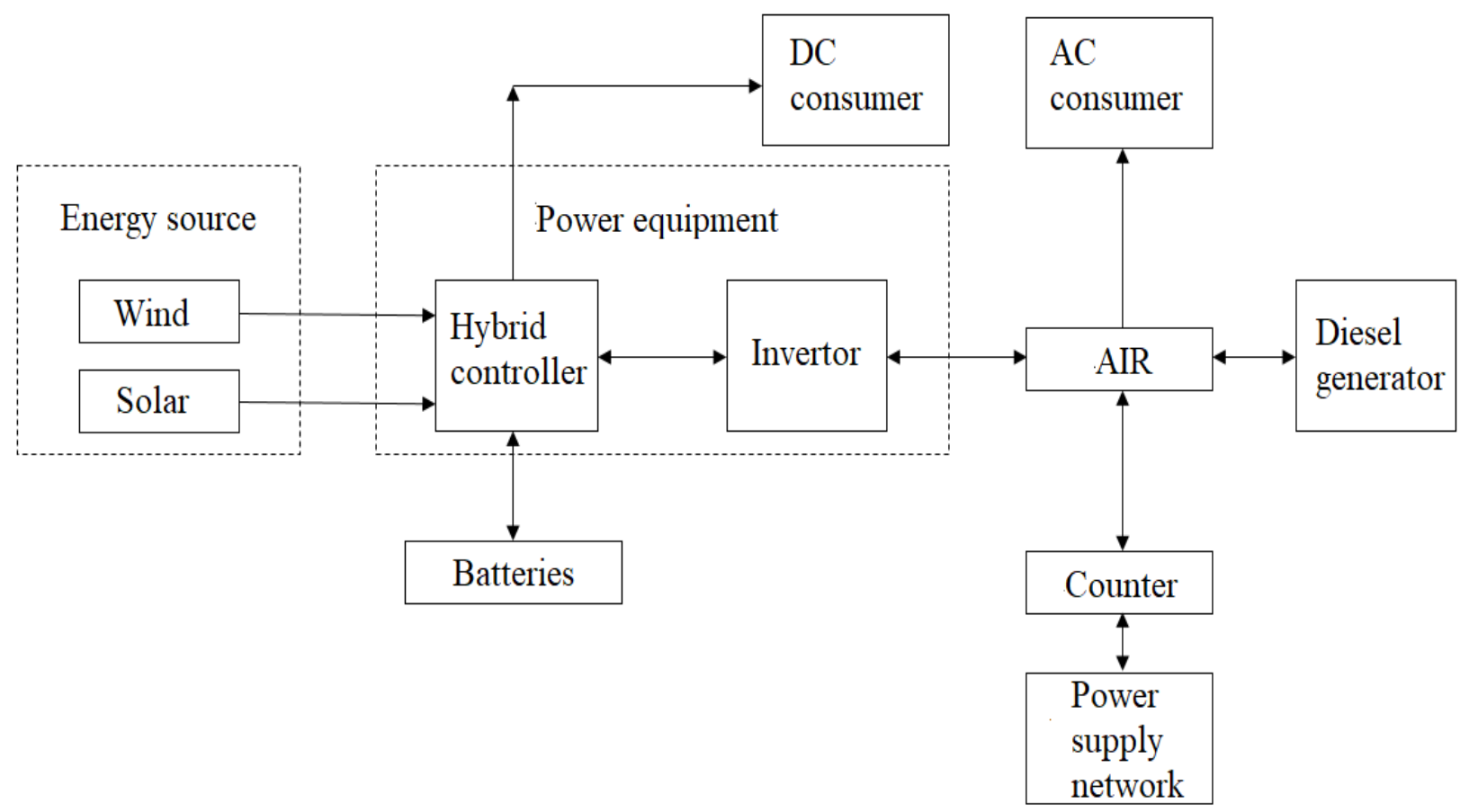

Fig. 1. Schematic diagram of power supply systems of energy efficient house of Institute of Engineering Thermophysics of NAS of Ukraine

The required amount of electricity production for the most efficient operation of an energy-efficient house is about $750 \mathrm{kWh}$ per month. To provide electricity to technical consumers of the house on a pitched roof at an angle of $33^{\circ}$ installed 22 single-crystal photovoltaic modules QSolar QS-240W with a capacity of $240 \mathrm{~W}$ and 60 polycrystalline photovoltaic modules Calyxo CX3 (based on cadmium telluride) with a capacity of $80 \mathrm{~W}$. For Kyiv, the recommended angle of maximum annual electricity generation (angle of inclination to the horizontal plane of photovoltaic modules) is $38^{\circ}$.

EPSolar eTracer ET6415N charge controllers are used to prevent emergency battery charging from photovoltaic converters and increase energy efficiency from photovoltaic modules.

In order to ensure the charging of the batteries from the wind turbine under these conditions at the appropriate speed and, taking into account the use of another energy source (including photovoltaic modules) to power the facility, it will be appropriate to install a device with a rated power of at least average hourly consumption. In this case, a Fortis Montana wind turbine with a rated power of $5 \mathrm{~kW} \mathrm{DC} 48 \mathrm{~V}$ with a built-in charge controller is used [3].

3 Axpert Abi - Solar KS - 5K inverters connected in parallel as part of the power supply system provide a constant load of $4 \mathrm{~kW}$ and a short-term load (up to 5 seconds) of $8 \mathrm{~kW}$.

The total capacity of the battery pack is selected based on the calculation of the sufficiency of three-day autonomous operation of the control of boiler with pellet burner, taking into account the depth of discharge up to $70 \%$ of the maximum allowable. AGM Ventura GPL12-100 batteries $(12 \mathrm{~V}, 100 \mathrm{Ah})$ are installed to ensure uninterrupted power supply.

Year-round monitoring of atmospheric parameters such as current values of wind speed and direction, relative humidity and barometric air pressure was carried out using a portable meteorological station TFA Nexus using appropriate Primus software, which allowed to collect and analyze measurement data.

\section{Results and discussion}

When using data from solar radiation, taken from climatic reference books and regulations [4], cloudiness and radiation properties of the atmosphere of this area are not taken into account, which cannot be calculated. The data from the reference sources themselves, today, need to be clarified in connection with climate change. Therefore, when selecting parameters and operating expensive equipment to convert solar radiation energy into heat, there is a need for refined parameters of insolation, which comes at different angles to the horizontal surface.

Data on insolation for the location of the energy-efficient house were obtained experimentally in 2019 using measurements with a pyranometer SR-U1 (Fig. 2), located on the roof of the building №1 at Kyiv, st. Bulakhovsky, 2. 


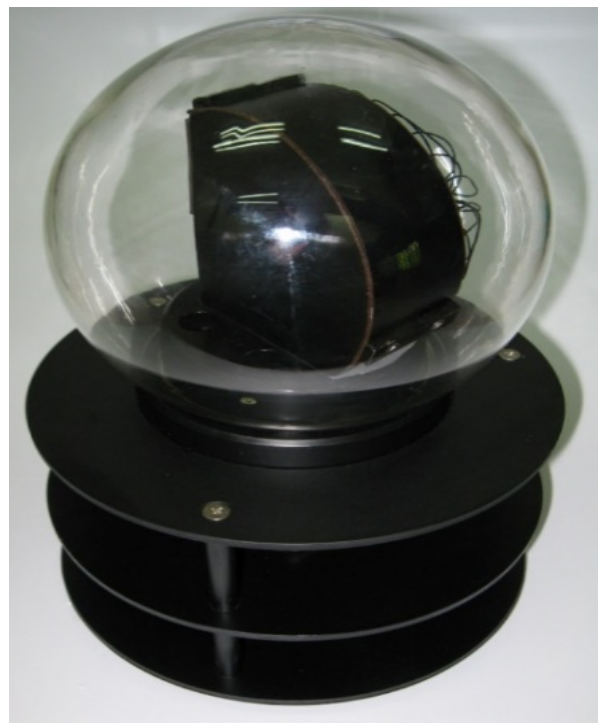

a)

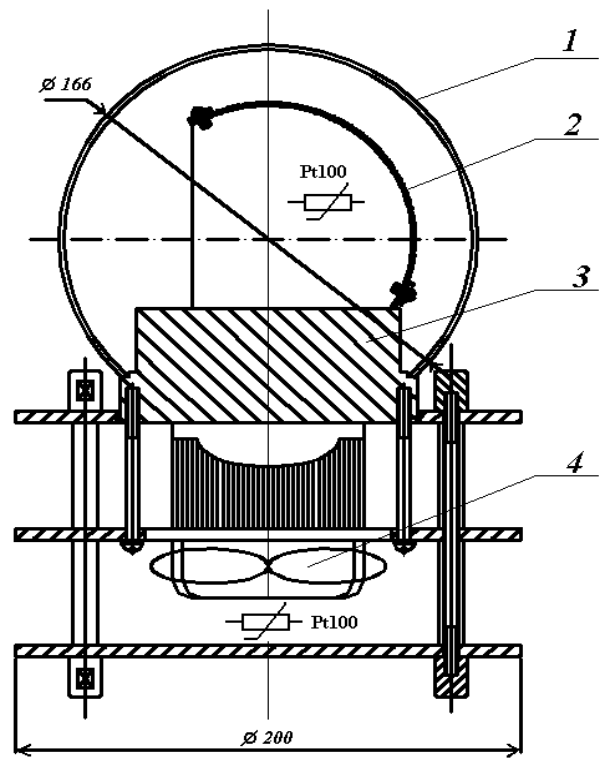

b)

Fig. 2. Pyranometer SR-U1

a) appearance, b) scheme: 1 - glass dome; 2 - multi-section heat flow converter (PTP); 3 - heat runoff; 4 forced cooling system.

Its design was developed in the Department of Thermometry of the Institute of Engineering Thermophysics of the NAS of Ukraine in Kyiv. The pyranometer belongs to the actinometric group and allows to determine the density of total solar radiation $\left(\mathrm{W} / \mathrm{m}^{2}\right)$ coming to the plane with an angle of inclination to the horizon from $0^{\circ}$ to $90^{\circ}$ with a step of $10^{\circ}$. Such data allow us to estimate the possible technically available potential for the use of solar radiation during the year for a given area.

It should be noted that the largest value of the energy of solar radiation enters the area of the converter of the pyranometer, which has an angle of inclination to the horizontal plane of $50^{\circ}$. At maximum cloudiness, this is the case for the surface, which is located at angles to the horizon $0^{\circ} \div 10^{\circ}$. This is due to the fact that in a cloudy sky, the maximum value of the diffuse component of solar radiation falls on the horizontal surface. Figure 3 shows the instantaneous values of the energy flow from insolation in December for the city of Kyiv at an angle of inclination of the surface of $33^{\circ}$ to the horizontal plane.

The calculation of electricity production by the solar station was performed in the PVSyst program according to meteorological data Meteonorm. The results of the calculation are presented in table 1.

Table 1 . The results of the calculation of electricity production by a solar station

\begin{tabular}{|l|c|c|c|c|}
\hline \multicolumn{1}{|c|}{ Month } & $\begin{array}{c}\text { Intensity of insolation } \\
\text { on a horizontal surface, } \\
\mathrm{kWh} / \mathrm{m}^{2}\end{array}$ & $\begin{array}{c}\text { Air } \\
\text { temperature, C }\end{array}$ & $\begin{array}{c}\text { The intensity of insolation on } \\
\text { the surface at an angle of } \\
30^{\circ} \text { to the horizontal, } \mathrm{kWh} / \mathrm{m}^{2}\end{array}$ & $\begin{array}{c}\text { Electricity is } \\
\text { received in } \\
\text { photovoltaic } \\
\text { modules, } \mathrm{kWh}\end{array}$ \\
\hline January & 28 & $-4,2$ & 42,4 & 339 \\
\hline February & 48 & $-3,7$ & 70,4 & 596 \\
\hline March & 88 & 1,9 & 109,6 & 947 \\
\hline April & 122 & 8,5 & 135,7 & 1163 \\
\hline May & 185 & 15,2 & 191,6 & 1470 \\
\hline June & 178 & 18,0 & 176,0 & 1459 \\
\hline July & 176 & 19,1 & 175,6 & 918 \\
\hline August & 156 & 18,5 & 170,0 & 802 \\
\hline September & 101 & 14,1 & 119,9 & 317 \\
\hline October & 67 & 8,0 & 95,5 & 247 \\
\hline November & 29 & 1,3 & 40,3 & 32,6 \\
\hline December & 21 & $-2,0$ & 32 & \\
\hline
\end{tabular}

ISSN 2308-7382 (Online) 


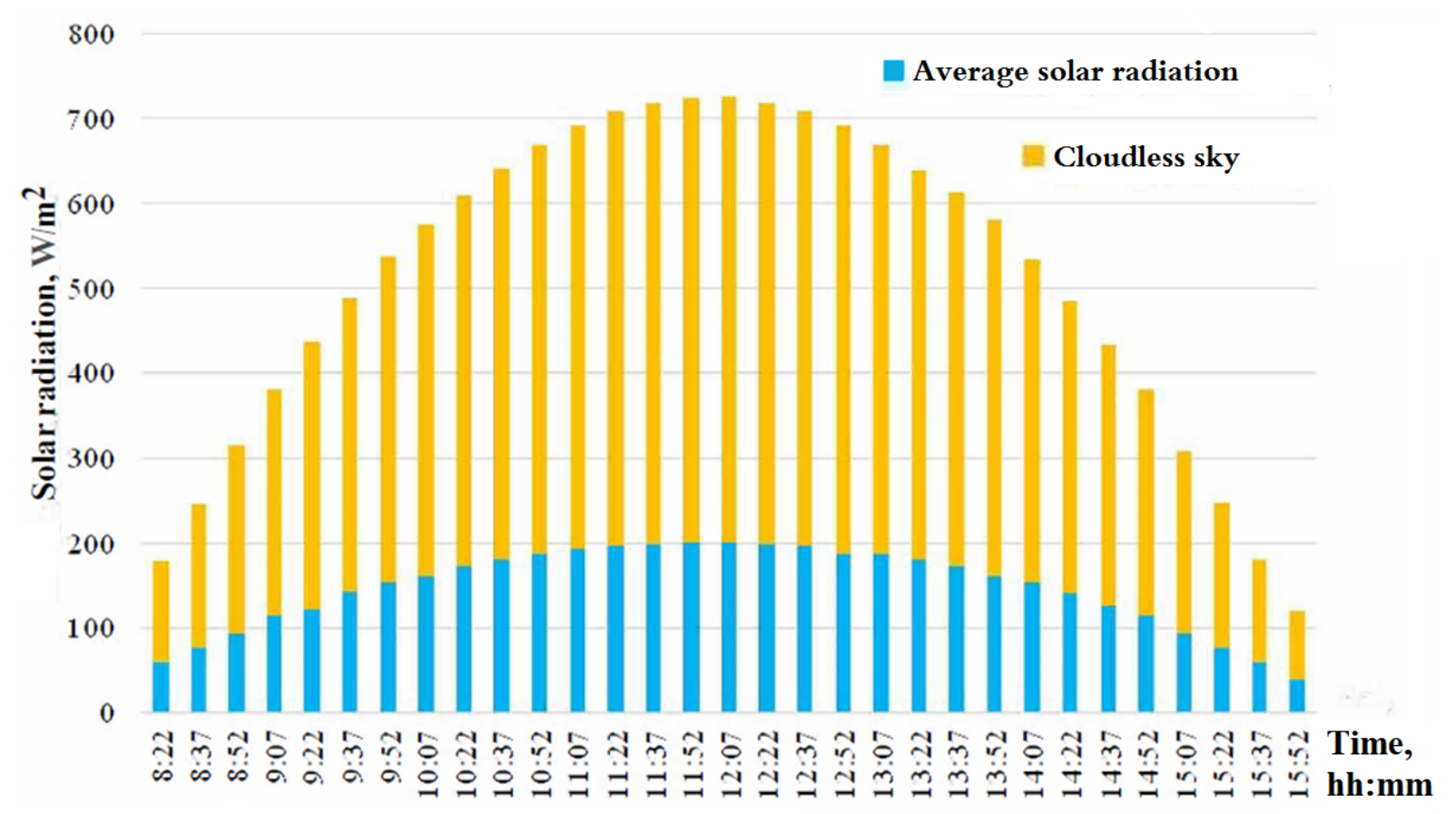

Fig. 3. Instantaneous value of energy flow from insolation to a surface with an angle of inclination of $33^{\circ}$ in December for the city of Kyiv

The results of the calculation of electricity production by the wind turbine are shown in table 2 .

Fig. 4 shows a histogram of the distribution of total electricity production by the complex system (solar and wind power plants) for 2019. When using such a wind generator in climatic conditions, it is possible to achieve an average monthly electricity production of about $285 \mathrm{kWh}$.

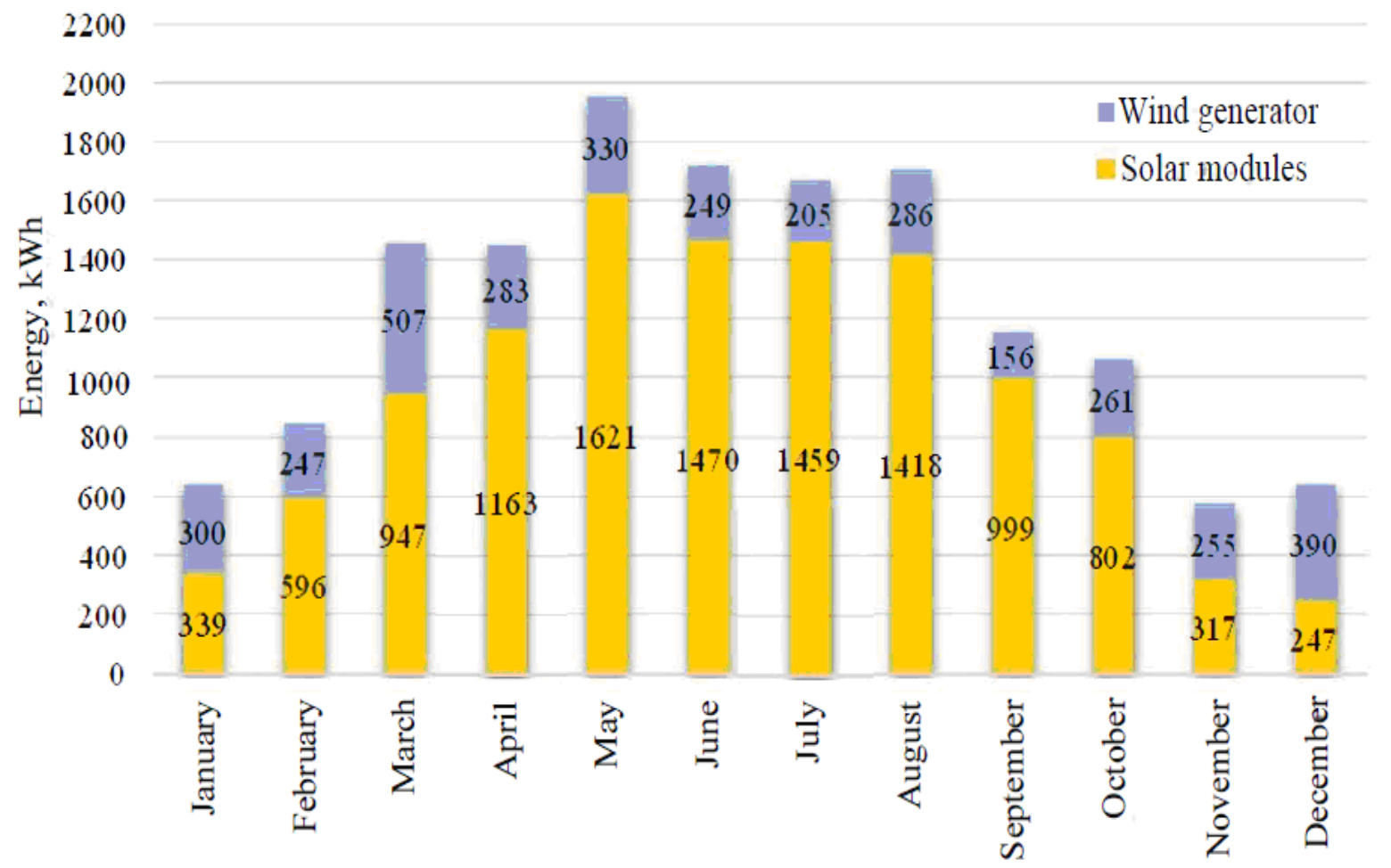

Fig. 4. Histogram of total electricity production by a complex system 
Table 2. The results of the calculation of electricity production by a wind turbine

\begin{tabular}{|c|c|}
\hline Month & Electricity production, $\mathrm{kWh}$ \\
\hline January & 300 \\
\hline February & 247 \\
\hline March & 507 \\
\hline April & 283 \\
\hline May & 330 \\
\hline June & 249 \\
\hline July & 205 \\
\hline August & 286 \\
\hline September & 156 \\
\hline October & 261 \\
\hline November & 255 \\
\hline December & 390 \\
\hline
\end{tabular}

At the same time, it should be noted that the energy contribution from photomodules is crucial for the power supply of an energy-efficient house.

Electricity produced by the complex system during the most favorable periods of the year sometimes reaches more than $2000 \mathrm{kWh}$ per month. The average daily production of electricity by this system is about $45 \mathrm{kWh}$.

\section{Conclusions.}

1. The proposed instrumental methods for determining the parameters of insolation provide an opportunity to assess its technically available potential for a given area, as well as to use the obtained data for the design of complex power supply systems using energy of wind and solar.

2. The research results prove that in the conditions of the city of Kyiv there are potential opportunities for the creation of residential buildings with zero energy balance, in which, for the purpose of power supply, wind generators and solar modules can be used quite successfully.

3. Estimates show that electricity from photovoltaic modules (total installed capacity of the solar station is $10,7 \mathrm{~kW}$ ) and wind turbine (rated power $5,0 \mathrm{~kW}$ ) is sufficient to provide an energy efficient house with a total area of $302 \mathrm{~m}^{2}$.

\section{REFERENCES}

1. Басок Б.И., Хибина М.А., Беляева Т.Г. Энергоэффективные дома типа «нуль энергии». Принципы создания и пути развития. Промышленная теплотехника, Т. 35. №6. 2013. С. 43 - 50.

2. Долінський А.А., Басок Б.І., Недбайло О.М., Бєляєва Т.Г., Хибина М.А., Ткаченко М.В., Новіцька М.П. Концептуальні основи створення експериментального будинку типу «нуль енергії». Будівельні конструкції. ВП. 77. 2013. С. 222 - 227.

3. Б.І. Басок, Т.Г. Бєляєва, І.К. Божко, О.М. Недбайло, В.Г. Новіков, М.А. Хибина Система

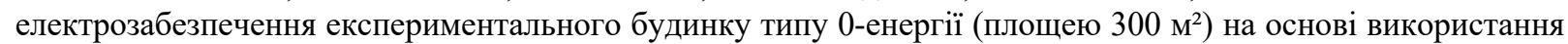
відновлюваних і альтернативних джерел енергії. Наука та інновації. 2015. Т. 11, № 6. C. 29 - 39 . DOI: doi.org/10.15407/scin11.06.029

4. Будівельна кліматологія: ДСТУ НБВ.1.1-27:2010 - [Чинний від 1 листопада 2011 р.]. - К. : Держспоживстандарт України, 2011. - 123 с. : табл. - (Національні стандарти України).

5. Басок Б.І., Жовнір М.С., Засецький І.Г. Електропостачання житлових будинків на основі відновлюваних джерел енергії. Енергетика. Екологія. Людина. Наукові праці НТУУ «КПІ», IEЕ. - Київ: НТУУ «КПІ», IEE, 2014. - С. $61-67$.

1. Basok B.I., Khibina M.A., Belyaeva T.G. Energoeffektivnyie doma tipa «nul energii». Printsipy sozdaniya i puti razvitiya. Promyishlennaya teplotehnika, T. 35. №6. 2013. P. 43 - 50.

2. Dolinskiy A.A., Basok B.I., Nedbailo O.M., Belyaeva T.G., Khibina M.A., Tkachenko M.V., Novitska M.P. Kontseptualni osnovy stvorennya eksperimentalnogo budinku tipu «nul energiyi». Budivelni konstruktsiyi. Vp. 77. 2013. P. $222-227$.

3. B.I. Basok, T.H. Byelyayeva, I.K. Bozhko, O.M. Nedbailo, V.H. Novikov, M.A. Khibina Systema elektrozabezpechennya eksperymental'noho budynku typu 0-enerhiyi (ploshcheyu $300 \mathrm{~m}^{2}$ ) na osnovi 
vykorystannya vidnovlyuvanykh i al'ternatyvnykh dzherel enerhiyi. Nauka ta innovatsiyi. 2015. T. 11, № 6. P. 29 - 39. DOI: doi.org/10.15407/scin11.06.029

4. Budivel'na klimatolohiya: DSTU NBV.1.1-27:2010 - [Chynnyy vid 1 lystopada 2011 r.]. - K. : Derzhspozhyvstandart Ukrayiny, 2011. - 123 p. : tabl. - (Natsional'ni standarty Ukrayiny).

5. Basok B.I., Zhovnir M.S., Zasets'kyy I.H. Elektropostachannya zhytlovykh budynkiv na osnovi vidnovlyuvanykh dzherel enerhiyi. Enerhetyka. Ekolohiya. Lyudyna. Naukovi pratsi NTUU «KPI», IEE. - Kyiv: NTUU «KPI», IEE, 2014. - P. $61-67$.

УДК 621.316

Б.I. Басок, д-р техн. наук, проф., ORCID 0000-0002-8935-4248

O.M. Недбайло, д-р техн. наук, старш. наук. співр., ORCID 0000-0003-1416-9651

I.K. Божко, канд. техн. наук, старш. наук. співр., ORCID 0000-0001-7458-0835

M.B. Ткаченко, канд. техн. наук, старш. наук. співр., ORCID 0000-0001-8345-1613

Інститут технічної теплофізики НАН України

\title{
ТЕХНІЧНІ ОСОБЛИВОСТІ ВИКОРИСТАННЯ КОМПЛЕКСНОЇ ВІТРО-СОНЯЧНОЇ СИСТЕМИ ЖИВЛЕННЯ ЕНЕРГОЕФЕКТИВНОГО БУДИНКУ
}

\begin{abstract}
Бажання досягти економії енергії органічного палива, зменшуючи негативний техногенний вплив на навколишнє середовище, особливо в умовах глобального потепління, спонукає до пошуку нових підходів у будівництві енергоефективних будинків та будівель. Аналіз накопичених метеорологічних даних про вітровий та сонячний потенціали Києва показує, щуо в місті можна створити повністю автономний будинок, який буде забезпечуватися електрикою за допомогою сонячної та вітрової енергї. Цілорічний моніторинг атмосферних параметрів, таких як поточні значення швидкості та напрямку вітру, відносної вологості та атмосферного тиску повітря, здійснювався за допомогою портативної метеорологічної станції TFA Nexиs за допомогою відповідного програмного забезпечення Рriтиs, щзо дозволяло збирати та аналізувати дані вимірювань. Дані про інсоляцію для розташування енергоефективного будинку були отримані експериментально у 2019 році за допомогою вимірювань 3 піранометром SR-U1. Розроблена система складається з вітрогенератора, сонячних модулів, контролерів заряду, інверторів та акумуляторів. Розрахунок виробництва електроенергї сонячною станцією проводився у програмі PVSyst за метеорологічними даними Меtеопогт. Водночас слід зазначити, щзо енергетичний внесок фотомодулів має вирішальне значення для електропостачання енергоефективного будинку. Запропоновані інструментальні методи визначення параметрів інсоляції дають можливість оцінити ї̈ технічно доступний потенціал для певної території, а також використовувати отримані дані для проектування складних систем електропостачання з використанням енергї вітру та сонячної енергії. Результати дослідження доводять, щ⿻ в умовах міста Києва існують потениійні можливості для створення житлових будинків з нульовим балансом енергї, в яких з метою електропостачання вітрогенератори та сонячні модулі можуть бути досить успішно використані.
\end{abstract}

Ключові слова: вітро-сонячна система електропостачання, виробництво електроенергії, інсоляція.

Надійшла 20.03.2021

Received 20.03.2021 